\title{
Countering Zeitgeist of Self-Centered through Role Playing Methods among Junior High School Students
}

\author{
Sandy Ariawan \\ Christian Education, STIPAK Malang, Indonesia \\ ariawan.sandy@yahoo.com
}

\section{Keywords:}

Self-centered, Role playing, Method,

\section{ABSTRACT}

This study aimed to examine the influence of role playing methods on the cognitive, affective, and psychomotor aspects of students in Christian education subjects, as an effort to counter zeitgeist of self-centered. Role playing method can give a strong and durable sense of learning in the students' memories, be a fun learning experience that is difficult to forget, make the classroom atmosphere more dynamic and enthusiastic, arouse passion and spirit in students and foster togetherness, allow students to plunge into the role of something that will be discussed in the learning process. This study is a quantitative research, with simple linier regression. Respondents are students of Public Junior High School 1 Wagir. From field trials and data processing that role playing implementation models have an impact of $34.8 \%$ while $65.2 \%$ are influenced by other factors. It is recommended role playing method as one of the appropriate method and practices in Christian education.

\section{Article History:}

Received: 03-11-2019

Revised : 27-12-2019

Accepted: 29-12-2019

Online : $30-12-2019$

This is an open access article under the CC-BY-SA license
https://doi.org/10.31764/ijeca.v2i3.2143

\section{A. INTRODUCTION}

If education is a conscious and well-planned endeavor, the goal of ultimately improving morale, forming a noble character and morality, is no longer the ability to be bidder and the participation of learners is absolutely necessary. The problem arises because the spirit of today, zeitgeist, is self-centered, who inevitably makes students apathy and engrossed in "his own world." It takes an extra hard effort from teachers to design the learning process so that students are interested in participating in teaching and learning activities (Mudjiono \& Dimyati, 2009). The aim of the study is to examine the influence of role playing methods on the cognitive, affective, and psychomotor aspects of students in Christian education subjects.

Bruce (Joyce \& Calhoun, 2009) says that role playing is a teaching model derived from the individual and social educational dimensions. This model helps each learner to find a personal meaning in their social world and helps solve a personal dilemma with the help of a social group. In the social dimension role playing makes it easy for individuals to cooperate in analyzing social conditions, particularly human problems. So this model is included in the model of social teaching because the role of an absolute part in human development. There is also its uniqueness is able to solve both interpersonal and social problems. Similarly expressed by 
Mulyatiningsih (Endang Mulyatiningsih, 2013), role playing is used to help learners understand the perspectives and feelings of others according to personality variations and social issues. According to Hamalik (Hamalik, 2008), role playing models are models of learning by giving certain roles to students and dramatizing the role on a stage. This model of learning is a model with the mastery of teaching materials through the development of the power of imagination and child passion.

Role playing is appropriately used in materials relating to social phenomena issues regarding human relationships, such as juvenile delinquency, unharmonious family depictions, or a person's biography. Topics that can also be lifted in role playing models are historical events or actual events and can also be on events that will happen in the future. Because researchers discussed the subject of Christianity so that being taken and used as a topic is a biblical story. Meanwhile, according to Tanya (Tanya Eli, 1999), this method is good for both adults and children, by portraying us to try to understand the thoughts, feelings, and behaviors of others.

Uno (Uno, 2010) confirms that this role playing process can provide examples of life's useful human behaviour as a means for students to: First, dig his feelings; Second, gain inspiration and understanding that affect their attitudes, values and perception; Third, develop skills and attitudes in solving problems; Fourth, learn the subjects in a variety of ways.

According to Hamalik (Hamalik, 2008), there are three role playing variations patterns, namely:

1. Play single role-play. The majority of Students act as pangamat against the game being performed. The goal is to form attitudes and values.

2. Play multiple role-play. Students are divided into groups of many members and their determination is adjusted to the number of roles required. Each participant holds and plays a specific role in the group respectively. The goal is also to develop attitudes.

3. Role repetition. The main role in a drama or simulation can be performed by each student in turns. In such situations each student learns to do, observe, and compare the behavior displayed by previous actors. The approach was widely implemented in order to develop interactive skills.

According to Muhibbin (Muhibbin Syah, 2013), role playing models in principle can serve as: 1) educational procedures and counseling are educative: 2) procedures of psychiatric therapy and medical counseling that are industrial. Its procedure consists of nine steps (Uno, 2010) namely,

1. Warming: Teachers are trying to introduce students to problems they realize as a thing that everyone needs to learn and master, and prepare the scenario to be shown.

2. Select a player: Students and teachers discuss the character of each player and determine who will play it.

3. Set up the stage: In this case the teacher discusses with the students where the role is played.

4. Observer: Teachers appoint several students as observers.

5. Role playing game starts. Role play is spontaneously performed.

6. Evaluation: The teacher with students discussed the game and evaluated the roles to be performed.

7. Repetition: If the first blackmail is less than the maximum, then it is repeated next time and is expected to be maximal. 
8. Evaluation II: Discussion of discussions and evaluations directed towards reality. Why so? Since the role is done, many roles are beyond the limits of reality.

9. Students are invited to share the experience of the role playing theme that has been continued by making conclusions.

The advantages that students have gained on role playing models are: give a strong and durable sense of learning in the students' memories, be a fun learning experience that is difficult to forget, make the classroom atmosphere more dynamic and enthusiastic, arouse passion and spirit in students and foster togetherness, allow students to plunge into the role of something that will be discussed in the learning process (Thomas H. Groome, 2011). While its weakness, such as: the amount of time needed, difficulty assigning specific roles to students if not trained properly, the possibility of applying role playing if the class atmosphere is not conducive, requires really mature preparations that will spend time and effort, not all subjects may be presented through this material.

According to Friedricks Frobel in Stevanus'book (Stefanus, 2009), the Christian education itself is spiritual experience both according to its process and purpose. So it is hoped that every believer really believes in his life that the education of Christianity is not merely a knowledge that fills the mind but leads to spiritual experience and character change, it can be ensured and made possible when the student grows to Christian education well in itself the achievement of learning will experience an increase of course there is an effort undertaken by each individual. Winkel (Winkel et al., 1999) gives the explanation of each aspects is as follows.

1) Cognitive Realm

a) Knowledge: It includes memory of things that have been learned and stored in remembrance. These can include facts, rules and principles and known methods. Knowledge stored in memory is dug up when it is needed through recall or recognition.

b) Understanding: The ability to include the meaning and meaning of the materials learned. This ability is expressed in describing the underlying contents of a reading.

c) Application: includes the ability to establish a rule or method of working on a concrete and new case/problem.

d) Analysis: includes the ability to detail a unity into parts, so that the overall structure or organization can be well understood.

e) Synthesis: includes the ability to form a new unity or pattern. Parts are connected to each other, thus creating a new shape.

2) Affective Realm

a) Acceptance: Includes the sensitivity of a stimulant and a willingness to pay attention to the stimulus, such as a textbook or explanation given to the teacher (Ariawan, 2018). The error is in paying attention to something, such as staring at a written image or listening to a classmate's answer to the teacher's question.

b) Participation: Includes willingness to actively pay attention and participate in an activity.

c) Assessment/Determination: includes the ability to give the assessment of something and carry itself in accordance with the judgment. Begin to form an attitude of accepting, rejecting or ignoring attitudes.

d) Organization: Includes the ability to establish a value system as a guideline and a grip in life. 
e) Formation of Life patterns: includes the ability to live up to the values of life in such a way, that it becomes a private property (internalization) and becomes a real and clear grip in the organizing of its own life.

3) Psychomotor Realm

a) Perception: Includes the ability to conduct proper discrimination between two or more stimulating, based on the distinction between the distinctive physical characteristics of each stimulus (Djiwandono, 2002).

b) Readiness: includes the ability to place itself in a state of starting a movement or series of movements.

c) Guided movement: includes the ability to perform a series of gestures according to the example given (imitation). This ability is expressed in moving the limbs, according to the examples shown and listened to.

d) The accustomed movement: includes the ability to perform a movement smoothly, because it is trained sufficiently without regard to the given example.

e) Creativity: It includes the ability to deliver new movements entirely on the basis of initiatives.

\section{B. METHODS}

This study is a quantitative research, with simple linier regression (Sugiyono, 2017). Respondents are students of Public Junior High School 1 Wagir. All respondents filled a valid and reliable questionnaire. Data is processed using SPSS 23.0.

\section{RESULT AND DISCUSSION}

\section{Simple Linier Regression}

Table 1. Variables Entered/Removed ${ }^{\mathrm{a}}$

\begin{tabular}{|l|l|l|l|}
\hline Model & \multicolumn{1}{|c|}{$\begin{array}{c}\text { Variables } \\
\text { Entered }\end{array}$} & $\begin{array}{c}\text { Variables } \\
\text { Removed }\end{array}$ & Method \\
\hline 1 & $\mathrm{X}^{\mathrm{b}}$ & & Enter \\
\hline
\end{tabular}

a. Dependent Variable: Y

b. All requested variables entered.

In the Table 1 above, it appears that the variable entered is variable $\mathrm{X}$, while the variable $\mathrm{Y}$ as the variable is bound (dependent).

Table 2. Model Summary

\begin{tabular}{|l|r|r|r|r|}
\hline Model & \multicolumn{1}{|c|}{$\mathrm{R}$} & R Square & $\begin{array}{c}\text { Adjusted R } \\
\text { Square }\end{array}$ & $\begin{array}{c}\text { Std. Error of } \\
\text { the Estimate }\end{array}$ \\
\hline 1 & $.590^{\mathrm{a}}$ & .348 & .310 & 4.662 \\
\hline
\end{tabular}

a. Predictors: (Constant), $\mathrm{X}$

b. Dependent Variable: Y

In the R Square table, the result appears to be 0.348 . This means that implementing role playing models affects the learning outcomes by $34.8 \%$, while $65.2 \%$ is influenced by other factors. 
Vol. 2, No. 3, December 2019, pp. 44-49

\section{Classic Assumption Test}

The classic assumption test is a statistical requirement that must be met on a linear regression analysis. In this study the classical assumption test consisted of a test of normality and heteroskedasticity which will be discussed as below.

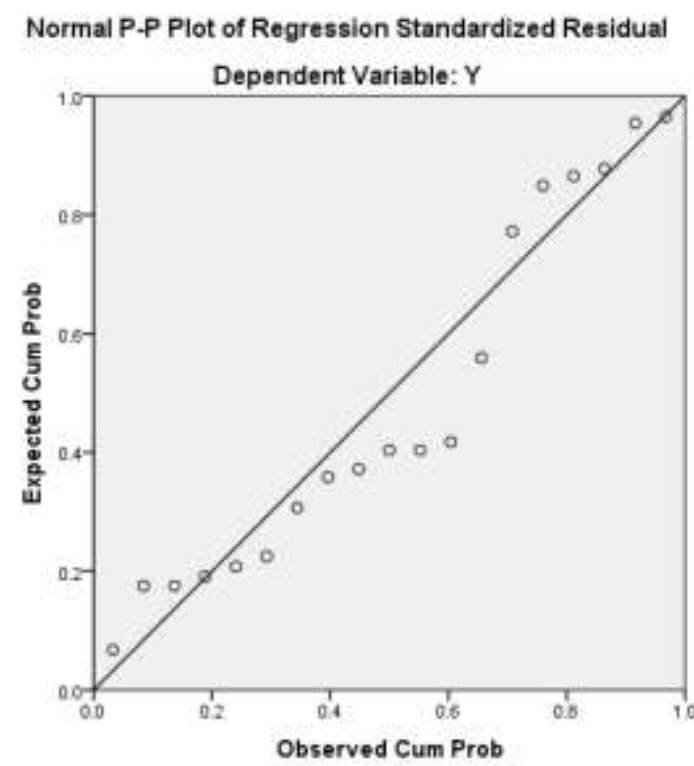

Figure 1. Normal P-P Plot

In the Figure 1 of the normality of the P-P Plot above appears that the residual is around the line, it means the data is distributed normally.

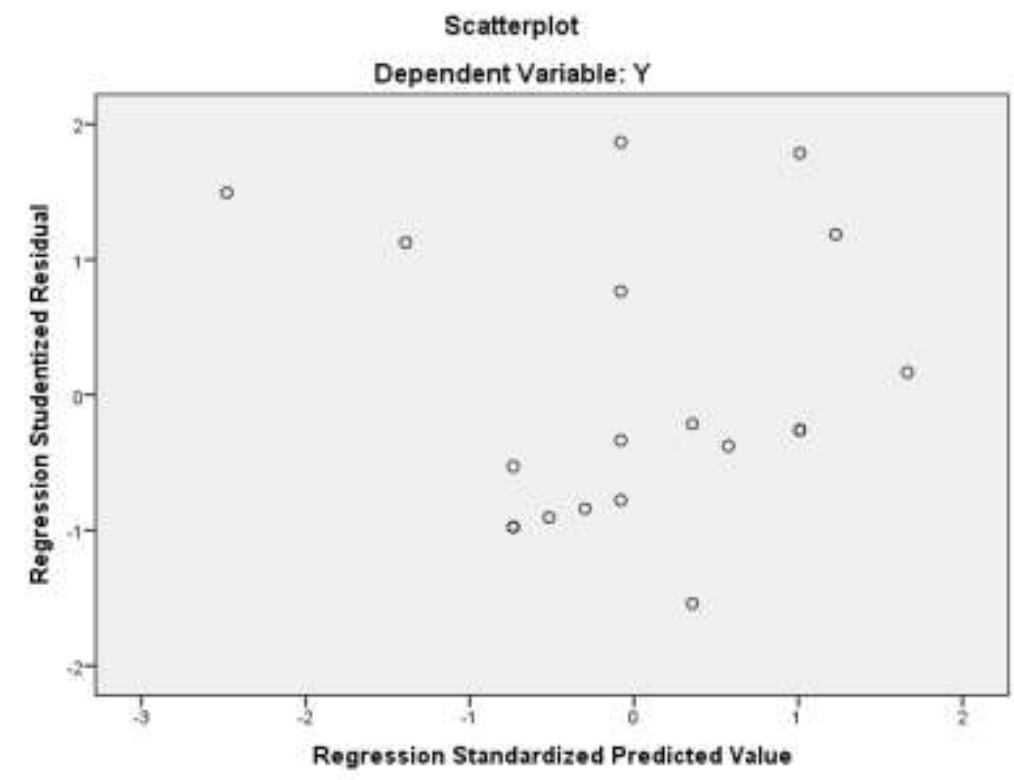

Figure 2. Scatterplot

On the Scatterplot Figure 2 above it appears that the dots do not form a particular pattern then this indicates that there is no problem of heteroskedasticity. 


\section{CONCLUSION AND SUGGESTIONS}

Students play the role and dramatize stories that are portrayed in such a way as to improve mental activity and soul so as to assess the circumstances or every behavior. The implementation of role playing model is consist of several stages: educators explaining the story to be in the role, choosing the roles that the teacher chooses students to be a role, the arrangement of the place where the teacher prepares the place to be used to role-play, the selection of observers that the teacher chooses the student as an observer, starting the cast of the students, the repetition is to fix the first one, the second evaluation discusses the cast and the teacher explains the value of truth on each cast, and in conclusion, the students are invited to share their experiences while playing the role and conclude from all the activities that have been done.

Optimal learning outcomes when students can absorb any material taught and lead to three spheres of cognitive where students can remember and understand and the material that has been explained and students are able to analyze the knowledge he has acquired, then affective that the students have an empathy attitude to others can then assess each deed so as to determine what should be done, as well as the latter being psychomotor, students experience a change of behavior. The emphasis of learning outcomes is on Christian education. From field trials and data processing that role playing implementation models have an impact of $34.8 \%$ while $65.2 \%$ are influenced by other factors.

\section{ACKNOWLEDGEMENT}

Gratitude for the help of the pricipal of Public Junior High School 1 Wagir and all parties involved.

\section{REFERENCES}

Djiwandono, S. E. W. (2002). Psikologi Pendidikan. Pt Gramedia Widiasarana Indonesia. Endang Mulyatiningsih. (2013). Metode Penelitian Terapan Bidang Pendidikan. Alfabeta.

Hamalik, O. (2008). Perencanaan Pengajaran Berdasarkan Pendekatan Sistem. In Dinamika Ilmu (Issue 01).

Joyce, B., \& Calhoun, E. (2009). Three Sides Of Teaching: Styles, Models, And Diversity. In International Handbook Of Research On Teachers And Teaching (Pp. 645-652). Https://Doi.Org/10.1007/978-0387-73317-3_39

Mudjiono \& Dimyati. (2009). Hakikat Belajar Dan Pembelajaran. Belajar Dan Pembelajaran, 1-46.

Muhibbin Syah. (2013). Psikologi Pendidikan. Pt Remaja Rosdakarya.

Stefanus, D. (2009). Sejarah Pak Tokoh-Tokoh Besar Pak. Bina Media Informasi.

Sugiyono. (2017). Sugiyono, Metode Penelitian. Penelitian, 34-45. Https://Doi.Org/10.1021/017029646

Tanya Eli. (1999). Gereja Dan Pendidikan Agama Kristen. Stt Cipanas.

Thomas H. Groome. (2011). Christian Religious Education. Bpk Gunung Mulia.

Uno, H. H. B. (2010). Model Pembelajaran: Menciptakan Proses Belajar Mengajar Yang Kreatif Dan Efektif. In Jakarta: Bumi Aksara. Https://Doi.Org/10.1038/Cddis.2011.1

Winkel, F. W., Blaauw, E., \& Wisman, F. (1999). Dissociation-Focused Victim Support And Coping With Traumatic Memory: An Empirical Search For Evidence Sustaining The Effectiveness Of Downward Comparison Based Interventions. International Review of Victimology, 6(3), 179-200. Https://Doi.Org/10.1177/026975809900600302 